\title{
Introduction: 'Religious Transformation in the Middle East: Spirituality, Religious Doubt, and Non-Religion in the Middle East'
}

\author{
Karin van Nieuwkerk
}

Citation: van Nieuwkerk, Karin 2021. Introduction: 'Religious Transformation in the Middle East: Spirituality, Religious Doubt, and Non-Religion in the Middle East'. Religions 12: 426. https://doi.org/ $10.3390 /$ rel12060426

Received: 30 May 2021

Accepted: 1 June 2021

Published: 9 June 2021

Publisher's Note: MDPI stays neutral with regard to jurisdictional claims in published maps and institutional affiliations.

Copyright: (C) 2021 by the author. Licensee MDPI, Basel, Switzerland This article is an open access article distributed under the terms and conditions of the Creative Commons Attribution (CC BY) license (https:// creativecommons.org/licenses/by/ $4.0 /)$.
Faculty of Philosophy, Theology and Religious Studies, Radboud University, 6525 XZ Nijmegen, The Netherlands; k.vannieuwkerk@ftr.ru.nl

The political impact-or rather the lack thereof-following the revolutionary uprisings in the Middle East has been well documented. Yet less is known about the religious transformation that has since taken place, with most attention having been dedicated to radical Islam, political Islam, Salafism, jihad, and the methods adopted to combat these currents. The development of 'moderate Islam', constructed as an antidote to these movements, has also been examined and critically assessed for its politicized character and the uncontested appraisal it receives from the West (Mahmood 2009). A development that has received less attention is the way that contesting political authorities both during and after the Arab upsurges has also affected religious authorities due to the intertwinement of religion and politics in different countries in the Middle East.

Since the 1970s, the emergence of mosque movements and the ensuing vocal piety discourses in the Middle East have been intensively studied, (e.g., for Egypt see Hirschkind 2001, 2006; Mahmood 2001a, 2001b, 2005; Deeb 2006 for Hezbollah, Lebanon) and light has been shed on their conservative religious nature. These authors have shown how the piety movement has instilled conservative-religious values through lessons and sermons, mediated across various different media platforms. The emergence of lay preachers striving to sell their pious messages to young people, and the subsequent effects on the middle and higher-middle classes, have also been widely discussed (e.g., for Egypt see Bayat 2002, 2005, 2007; Haenni 2002, 2005; Van Nieuwkerk 2013). Piety has become visible across the religious landscape, through an increase in the number of mosques, veiling (hijab and niqab), the growing of beards, and the appearance of the ' $z i b i b^{\prime}$ ', the dark spot on the forehead of Muslims which indicates the frequency of touching the prayer mat. This has illustrated the embodied nature of the region's omnipresent piety movement. Yet how have the recent upsurges in the Middle East affected the discourses surrounding both the conservative pious ones and the clearly politicized ones, such as Salafist movements and the Muslim Brotherhood?

This Special Issue draws attention to some of the many religious transformations currently emerging in the Middle East which diverge from the dominating rhetoric surrounding 'radicalization', 'political Islam', or the increase in religious fervor and piety among believers. Without denying that these tendencies are highly relevant and continue to play a crucial role in the region, we would like to point out other currents that seem to be coming more to the fore after the uprisings. The contemporary realities of religious ambivalence and 'imperfection' (Al-Ajarma, this issue), leaving the Muslim Brotherhood (Menshawy, this issue), religious doubts and critical thinking (Franke, this issue), looking for alternative forms of spirituality or individualized piety (Franke; Kütük-Kuriş; Van Nieuwkerk, this issue), de-veiling (Kütük-Kuriş; Van Nieuwkerk, this issue), and different forms of non-conformism, free-thinking, non-belief, and atheism (Franke; Richter; Elsässer, this issue) have all been considered.

The revolutionary uprisings appear to have affected religiosity in the Middle East in a myriad of ways. Firstly, there appears to be a transformation in the legitimacy of the 
sources of religious inspiration. Lay preachers, such as the Egyptian 'Amr Khalid, have become less attractive to younger generations of the revolutions in their aftermath. The same holds true for authoritative institutions such as al-Azhar and the Coptic Church. They are deemed to have taken the 'wrong side' of the revolution and accordingly lost their credibility in the eyes of young revolutionaries. The Muslim Brotherhood, with its slogan 'Islam is the solution', has also proven to be ineffective, at least in the context of the one-year rule of President Morsi in Egypt. In combination with the outright repression of its members by the Egyptian state, many members have been disappointed by the Muslim Brotherhood's performance and numerous members, including those of high-ranking, have resigned (Menshawy, this issue). Moreover, atrocities committed in the name of Islam by Da'ish/ISIS have driven people away from religion or at least made them question what Islam really is (see also Elsässer, this issue). Authoritative institutions, such as alAzhar, have mostly argued that 'this is not Islam', yet with these violent acts having been committed in the name of Islam, uncertainty has been raised about who decides what counts as Islamic. This has created aversion against certain interpretations of Islam and driven many people reflect on their own understanding of their religion. Young people have started to question religion in its hegemonic and political forms, looking for various alternatives, both inside and outside of religion.

Secondly, the sheer experience of being involved in the historic moments of the uprisings, as part of a collective body toppling powers that had been ruling for decades, has had an empowering effect on many protesters (see also Van Nieuwkerk 2021). The ex-Coptic activist Alber Saber, who participated in the Egyptian Kifaya movement before the revolution, asked: "Do you think someone who would take to the streets before the revolution and who chanted against Mubarak would be afraid to reveal their beliefs?"1 One of my interlocutors explained how this feeling of empowerment during the revolution and the downfall of Mubarak spilled over into questioning religious authority:

"I started to see people actually changing after the revolution. ( . . ) The idea of saying no! You said no to a superior power that we thought it would never fall. This is a part of the system that you have been growing into, is falling apart! So, there is another system, a fundamental one in Egypt, that is, the religion. So still you can say no!". 2

This did not stop at questioning state and religious authorities but also reached the third pillar of authority in Egypt: parental authority or patriarchy, as several other interlocutors remarked:

"Actually, after the revolution, we start rethinking everything in our life, from politics, religion, what goes on your family, the relationship with your father to the ties with your friends. You start questioning everything". 3

Accordingly, there appears to be a crisis in religious authority, not only because of its fragmentation but also as a result of the effect of contesting all kinds of authorities, particularly political, religious, and patriarchal.

Thirdly, the wide accessibility of social media as a source of information has enabled young people to actively question received ideas and search for information on alternative forms of religiosity and spirituality. Social media has been a helpful political tool for organizing the uprising itself, also proving valuable in contesting religious authorities. Exploring other religions, usually dismissed as 'unbelief', and finding many similarities between religious systems, has made young people aware of the relativity of religious claims to truth. In other words, if all religions seem to believe that they hold the absolute truth, how do I know my religion is the only right one? Thus, many questions are raised about the plausibility and undisputed status of the religion one was born in. What often manifests is a renewed commitment towards searching whether Islam or Christianitydepending on the religion in which one was raised-can truly possess the ultimate truth. It further encouraged reflection on one's own understanding of religion. While this reflective 
process can strengthen and deepen religiosity, it can often lead to a more personalized version of piety.

Whilst Sufism appears to have become more attractive to young people, New Age spirituality and Buddhism can also stake claim to a rise in popularity. Rather than the available conservative piety discourse that stresses the significance of ritual, doctrine, outward conduct and religious commands, people search for personal forms of religiosity and piety. Whereas removing the hijab can be a sign of religious doubts and questioning, it can also represent a search for a more inward-oriented piety instead of the outwardoriented forms of the existing piety movements. As Kütük-Kuriş and Van Niewkerk (both this issue) unearth, this can manifest in young Muslim women taking off the veil whilst simultaneously feeling spiritually close to God than ever before.

The advent of widespread internet access has enabled young people to explore nonbelief and atheism, fields that are strongly detested and feared within society. Yet, critical thinking about religion is nothing new to the region. Isma'il Adham was famed for writing an essay in 1937 in Arabic entitled "why I am an atheist." Yet, after the decline of leftist and communist ideas in the Middle East, as well as the rise of Islamic movements around the 1980s, atheism has become confined to small academic circles. Western New Atheism of the 21st century, however, has transformed the Arabic intellectual scene due to the circulation of translated video clips and lectures on the internet, as well as the translation of some major works such as Dawkins' (2006) The God Delusion.

Various forms of freethinking, nonbelief and (new) atheism have gradually become available online, promoted by an active youth blogging movement and YouTubers from the Arab Atheist Network. Young nonbelievers all over the Middle East realized they were not the only ones with religious doubts and founded an online community of likeminded people and activists (see also Richter, this issue). Before the uprisings, nonbelievers' media, Facebook pages, and YouTube channels had already existed but it was only after the revolutions that they really began to mushroom. Whilst numerous Atheist Facebook groups were in circulation by the late 2000s, the transition of some activists from the relatively closed and limited sphere of social media groups to YouTube has represented a new stage in this development (see Elsässer, this issue). Such a shift cannot be explained by social media dynamics alone but is also embedded in wider social and political developments, especially in Egypt, where many of the YouTube activists come from. Famous freethinkers and atheists such as Hamed Abdel-Samad, Sherif Gaber, Adam Elmasri and Kosay Betar have a large international audience (see Elsässer, this issue).

It is of course difficult to assess whether nonbelieving is a growing trend among young people in the Middle East. Due to the sensitivity and stigma surrounding the topic, as well as the harmful legal and societal consequences, many nonbelievers refrain from discussing their convictions (see also Richter, this issue). Yet since the uprisings and the spread of relatively safe and anonymous spaces on social media, many people have begun to speak out. Although it is not easy to measure whether there is a growing trend or that more people are simply daring to speak out, there are indications which suggest an increase in those self-identifying as non-religious. As the Arab Barometer (Figure 1) points out, the number of people in the Middle East identifying as "not religious" has risen from $8 \%$ in 2013 to $13 \%$ in 2018. Only Yemen saw a fall in this category. According to this source, this change has been most prominently experienced by those under 30 , among whom $18 \%$ identify as 'not religious'. ${ }^{4}$ Based on the research tools by the Arab Barometer, the table below shows an increase in self-identified nonbelievers or agnostics in several countries in the Middle East since 2011, the year of the uprisings. ${ }^{5}$ 


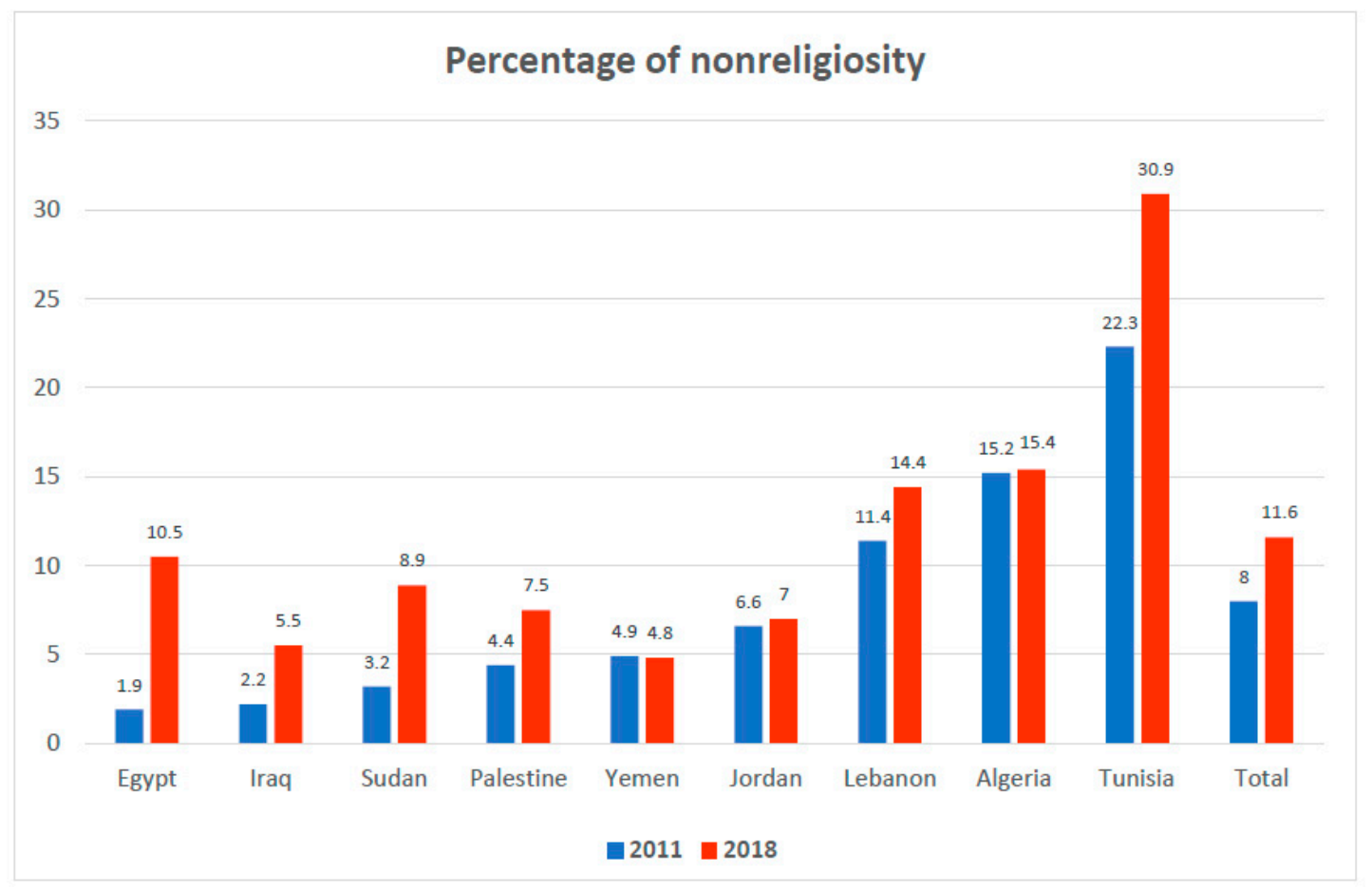

Figure 1. Non-religiosity (Source: Arab Barometer).

The upsurge in doubts and the questioning of beliefs has not gone unnoticed amongst religious authorities and state actors, provoking intense debates on how to counter this trend of non-religiosity and 'spiritual crises'.

This special issue consists of a cross section of current works in social science, religious studies, and related fields on Islam/religion and non-religion in the Middle East. The articles focus on spirituality, religious doubts and non-religion by presenting case studies from different countries in the Middle East, with examples from Turkey, Morocco, and Egypt. The article on freethinkers and nonbelievers on social media includes the reflections of participants from Syria and the diaspora. Despite the diversity of the case studies, there are striking similarities in the authors' observations on important social trends.

Firstly, as discussed above, several authors note the importance of social media as a relatively safe and anonymous space, suitable for exploring and expressing sensitive issues and non-conformist ideas, be it religious doubt, alternative forms of spirituality, agnosticism or nonbelief. The availability of smart phones and personal computers, where people can search for information on topics which they would not dare to investigate in an internet café or on a shared computer at home, also provides space to delve into sensitive topics. Yet in the current environment following the Arab uprisings, surveillance has not disappeared; rather it has become more advanced (Richter, this issue). Accordingly, even within these relatively safe online spaces people can be exposed and persecuted by state laws concerning, for instance, blasphemy. In many countries in the Middle East-even where there may be official freedom of religion - there is not always freedom of expressing critical views on religion, let alone nonreligious views. For instance, in Morocco, Article 220 of the Penal Code criminalizes "shaking the faith of a Muslim". Blasphemy, the disrespect of religious practices, and the violation of public morality and virtue are strictly forbidden as well (Richter this issue).

Nonbelievers, doubters, and freethinkers are then obliged to employ different tactics of hiding, only disclosing their doubts, critical views, or non-beliefs to like-minded friends. In other words, they live "secret lives" (Van Nieuwkerk 2018), or use various ways of "wrapping" their selves (Franke, this issue). Non-practicing Muslims or nonbelievers might wrap themselves in "Muslimness" in order to please others, or use wrapping techniques such as hiding, silence, and pretending to pray or fast. Another interesting tool, discussed 
by Richter (this issue), is the use of humor in online forums, which can also be understood as a form of "wrapping" criticism. Non-religious humor can be seen as a way to covertly express dissent in a context in which religious authority is omnipresent and closely linked to political legitimacy (Richter, this issue).

Secondly, several articles in this special issue point to the development of individualized forms of religiosity. The process of individualization is an important force that contests social and religious pressure towards conformity. With regards to unveiling, Van Nieuwkerk (this issue) shows that both her religious and nonreligious interlocutors took off the hijab as a way of discovering their own personalities and desires. In doing so, they uncovered their own way of being (non) religious, discarding the hegemonic piety discourse which compels women to veil. Against societal and religious pressure, they explored their own sense of self and femininity. The same holds true for the Turkish case, as analyzed by Kütük-Kuriş (this issue), where de-veiling can be regarded as particularly remarkable considering it has taken place under almost two decades of rule by the Islam-friendly AKP. In the Turkish context, the headscarf is often perceived to signal political alliance with $\mathrm{AKP}$, leading some women to de-veil, as they have grown tired of their appearance being associated with the ruling party. Accordingly, despite similarities in the experiences of women who take off the veil as an expression of desire to uncover their own selves, this process takes place in quite different socio-political contexts.

Franke (this issue) also shows that her interlocutors stressed their autonomous perspectives on religion. They reflect upon how to be religious or how not to be religious, how to believe or how not to believe, how to practice or how not to practice, what to wear or not to wear. In the case of disengagement from the Muslim Brotherhood, former members' sense of self, in particular how they use "their mind" and "independent reading" to mull over alternative ideas, has proven essential for the process of exiting from the collective body (Menshawy, this issue). Yet, as Al-Ajarma highlights (this issue), we should not underestimate the enduring force of family and society to make people conform to social expectations. Al-Ajarma studies Moroccan pilgrims' after-hajj experiences and the negotiations required to keep up with the social expectations that come with making the pilgrimage. She shows that pilgrims' good conduct is not merely a matter of private conduct but is displayed and assessed in the public arena. Therefore, pilgrims have to negotiate their new status within the mundane and complex reality of everyday life. Accordingly, there are many ambivalences and tensions which pilgrims have to deal with upon their return to Morocco.

This brings us to the third cross-cutting theme. Connected with the previous trend of individualization, several authors point to the presence of ambiguities in (non) religious trajectories. Inspired by the debate within the anthropology of Islam in terms of 'the everyday' (Schielke and Debevec 2012) and 'lived religion' (McGuire 2008), these authors examine the contradictions revealed in the lived experiences of their (non) religious interlocutors. Al-Ajarma, Franke, Kütük-Kuriş, and Van Nieuwkerk (this issue) all demonstrate that their interlocutors have diverse and often conflicting desires and ambitions, with regards to educational activities and successful professional lives, engaging in sports or leisure activities or experiencing love and gratifying relationships. Inspired by scholars like Schielke (2009), Deeb (2015), and Beekers and Kloos (2017), these authors show the ways in which Muslim subjects negotiate the norms of Islamic piety in order to achieve these numerous objectives in life. As a result, it is crucial to regard religious doubt as a highly complex process which does not relate well to fixed positions and binary categories.

Al-Ajarma (this issue), for instance, investigates the ways in which Muslim subjects live with moments of imperfection and ambivalence that are innate to human experience, by concentrating on moral flexibility in her interlocutors' discourses and practices. She argues that these moments of doubt and religious weakness can be 'productive'. Her research builds on the insights of Beekers and Kloos (2017) and De Koning (2017), who argue that a self-perceived sense of failure offers an important and productive entry point for the study of lived religion. The acknowledgement of moral failure can result in a constant effort of self- 
fashioning. Taking these insights one step further, Al-Ajarma argues that acknowledging one's sense of failure can be a 'technique of the self' in which the sense of failure is rechanneled into a moment of learning which then fuels further pious self-cultivation. Yet, conversely, the very same process of ambivalence, and the experience of conflicting desires and ambitions, can also be a productive means of questioning and disengaging from pious discourses and expectations. Cases of unveiling in Turkey (Kütük-Kuriş, this issue) and Egypt (Van Nieuwkerk, this issue), as well as leaving the Muslim Brotherhood (Menshawy, this issue) have neatly illustrated how this can materialize. Despite their similarities, studying daily lived contradictions, ambivalences, and sense of failure underscores the importance of carefully contextualizing the socio-political circumstances within these different case studies.

Finally, several authors show that 'religion' and 'non-religion' are not opposing categories but can intersect in daily lived experiences. This observation is connected to the growing body of literature that attempts to deconstruct the religious-secular divide (see e.g., Asad 2003; Hirschkind 2010). In this regard, it is useful to examine the terminology for non-religion and atheism in the Arab context. Elsässer, (this issue) following Schielke (2013), points out that "atheism" might be a misnomer in the contemporary Arab world, as the common Arabic word used to refer to atheism, ilhad, does not necessarily imply an ontological stance on the existence or non-existence of God. Neither does the neologism la-dini, which simply negates belonging to a religion (din). This could mean that in the contemporary Arab context, "the dividing line between theism and atheism is often less important than one's stance towards other key issues of a religious worldview" (Schielke 2013, p. 639).

The importance of breaking down the fixed boundaries between religion and nonreligion is brought to life by Van Nieuwkerk's study on unveiling in Egypt (this issue). Unveiling appears to be a fundamentally religious issue and is certainly perceived as such by many (religious) observers in Egypt. Without denying the relationship of unveiling to (non)religion, Van Nieuwkerk demonstrates that the religious dimensions only scratch the surface of the profound issues underlying unveiling. The narratives of womenwhether religious or nonreligious-who unveiled show that unveiling is part of a process of uncovering the self in its manifold aspects. By dismantling rigid dichotomies between the 'believers' to the 'non-believers', profound commonalities between them became clear. The motives behind unveiling are more about a battle over women's (rebellious) minds and bodies more generally, rather than their religiosity per se.

Accordingly, this special issue taps into important religious transformation processes presently emerging in the Middle East that have previously received less attention within scholarly literature. Processes such as individualized spirituality, forms of freethinking and non-conformism, as well as religious disengagement and disassociating from faith are all astutely brought into consideration. Moreover, the contributions also provide highly relevant insights for several contemporary debates that are crucial in the social sciences and religious studies. This includes processes of individualization; the study of everyday lived (non) religion; the anthropology of doubt, ambivalence and ambiguity; and last but not least, the deconstruction of the religious-secular divide, a divide that is seen as almost impenetrable according to many actors in the Middle East.

Funding: This research received no external funding.

Informed Consent Statement: Informed consent was obtained from all subjects involved in the study.

Data Availability Statement: The data are not publicly available due to the sensitivity of the topic and protection of the interlocutors.

Conflicts of Interest: The author declares no conflict of interest. 


\section{Notes}

1 http:/ / www.dailynewsegypt.com/2013/01/27/alber-saber-brotherhood-will-drive-the-people-to-secularism.html (accessed on 10 June 2015).

2 Interview with author 21st of January 2018.

3 Interview with author 13th of February 2015.

4 See https:/ / www.bbc.com/news/world-middle-east-48703377 for a comparison of the 2013 and 2018 waves (accessed on 17 June 2019).

5 Data taken from the Arab Barometer, which provides tools for analysis of the dataset collected in five waves between 2008 and 2018. People were asked to identify as religious, somewhat religious, nonreligious, or 'don't know'. https://www.arabbarometer. org/survey-data/data-analysis-tool/ (accessed on 7 October 2019). Libya, Kuwait and Morocco are included in the BBC analysis, which slightly increases the percentage of nonreligious people to $12.8 \%$. Since these countries were not included in the second wave (2011), I have left them out.

\section{References}

Asad, Talal. 2003. Formations of the Secular. In Christianity, Islam, Modernity. Stanford: Stanford University Press.

Bayat, Asef. 2002. Piety, Privilege and Egyptian Youth. ISIM Review 10: 23.

Bayat, Asef. 2005. What is Post-Islamism? ISIM Review 16: 5.

Bayat, Asef. 2007. Making Islam Democratic. In Social Movements and the Post-Islamist Turn. Stanford: Stanford University Press.

Beekers, Daan, and David Kloos, eds. 2017. Straying from the Straight Path: How Senses of Failure Invigorate Lived Religion. New York and Oxford: Berghahn Books.

Dawkins, Richard. 2006. The God Delusion. London: Bantam Press.

De Koning, Martijn. 2017. 'I'm a Weak Servant': The Question of Sincerity and the Cultivation of Weakness in the Lives of Dutch Salafi Muslims. In Straying from the Straight Path: How Senses of Failure Invigorate Lived Religion. Edited by Daan Beekers and David Kloos. New York and Oxford: Berghahn Books, pp. 37-53.

Deeb, Lara. 2006. An Enchanted Modern: Gender and Public Piety in Shi'i Lebanon. Princeton: Princeton University Press.

Deeb, Lara. 2015. Thinking Piety and the Everyday Together: A Response to Fadil and Fernando. Hau: Journal of Ethnographic Theory 5: 93-96. [CrossRef]

Haenni, Patrick. 2002. Au-delà du repli identitaire. Les nouveuax prêcheurs égyptiens et la modernisation paradoxale de l'islam. Religioscope novembre 2002 Also. Available online: http://www.religioscope.com/articles/2002/029_haenni_precheurs.htm (accessed on 20 November 2020).

Haenni, Patrick. 2005. L'islam de marché. L'autre révolution conservatrice. Paris: Seuil.

Hirschkind, Charles. 2001. The ethics of listening: Cassette-sermon audition in contemporary Egypt. American Ethnologist 28: 623-49. [CrossRef]

Hirschkind, Charles. 2006. The Ethical Soundscape. Cassette Sermons and Islamic Counterpublics. New York: Columbia University Press.

Hirschkind, Charles. 2010. Rethinking Secularism. Is there a Secular Body? The Immanent Frame, Secularism, Religion, and the Public Sphere. Available online: http:/ / blogs.ssrc.org/tif/2010/11/15/secular-body/ (accessed on 22 June 2012).

Mahmood, Saba. 2001a. Feminist theory, embodiment, and the docile agent: Some reflections on the Egyptian revival. Cultural Anthropology 6: 2002-36. [CrossRef]

Mahmood, Saba. 2001b. Rehearsed spontaneity and the conventionality of ritual: Disciplines of salat. American Ethnologist 28: 827-53. [CrossRef]

Mahmood, Saba. 2005. Politics of Piety. The Islamic Revival and the Feminist Subject. Princeton and Oxford: Princeton University Press.

Mahmood, Saba. 2009. Feminism, Democracy, and Empire: Islam and the War on Terror. In Gendering Religion and Politics. Untangling Modernities. Edited by Hanna Herzog and Ann Braude. London: Palgrave MacMillan, pp. 193-216.

McGuire, Meredith B. 2008. Lived Religion: Faith and Practice in Everyday Life. Oxford: Oxford University Press.

Schielke, Samuli, and Liza Debevec, eds. 2012. Introduction. In Ordinary Lives and Grand Schemes: An Anthropology of Everyday Religion. New York: Berghahn.

Schielke, Samuli. 2009. Being Good in Ramadan: Ambivalence, Fragmentation, and the Moral Self in the Lives of Young Egyptians. The Journal of the Royal Anthropological Institute 15: S24-S40. Available online: www.jstor.org/stable/20527687 (accessed on 13 June 2012).

Schielke, Samuli. 2013. The Islamic World. In The Oxford Handbook of Atheism. Edited by Stephen Bullivant and Michael Ruse. Oxford: University Press, pp. 638-50.

Van Nieuwkerk, Karin. 2013. Performing Piety. Singers and Actors in Egypt's Islamic Revival. Austin: University of Texas Press.

Van Nieuwkerk, Karin, ed. 2018. Moving in and out of Islam. Austin: University of Texas Press.

Van Nieuwkerk, Karin. 2021. The Atheist Spring? Emerging Non-belief in the Islamic World. The Cambridge History of Atheism. Cambridge: Cambridge University Press, vol. 2, pp. 1040-58. 